\title{
John Dewey's Democracy and Education and the Problem of Education in the Philippines
}

Marella Ada V. Mancenido-Bolaños

\begin{abstract}
In this paper, I will discuss how John Dewey's philosophy of education, specifically the relationship between education and democracy, and its possible contribution to the Philippine educational system. The paper will go through the following steps: 1) discuss Dewey's critique of the traditional pedagogy, 2) discuss the role of education in the development of students, 3) discuss the role of democracy in education and lastly, discuss education in the Philippine Context.
\end{abstract}

Keywords: Dewey, democracy, education, Philippine educational system

] t seems puzzling that while Dewey's book mentions democracy in its title, the book does not offer a thorough discussion of the concept of democracy. Perhaps because, as Peters claimed, "Dewey viewed democracy mainly as a way of life; he was not particularly interested in the institutional arrangements necessary to support it."1 Alongside communication, democracy is characterized by shared interests and concerns. Meanwhile, education, which Dewey describes as growth that is not to be equated with age, has to do with conditions which "ensure growth or adequacy of life." 2 In Philosophy of Education, Dewey claims that "the foundation of democracy is faith in the capacities of human nature; faith in human intelligence and in the power of pooled and cooperative experience." 3

\footnotetext{
${ }^{1}$ R.S. Peters, John Dewey Reconfigured (USA: Routledge and Kegan Paul, Ltd., 1977), 66. ${ }^{2}$ Ibid., 67. 59.

${ }^{3}$ John Dewey, Philosophy of Education (New Jersey: Littlefield, Adams and Co., 1975),

(C) 2016 Marella Ada V. Mancenido-Bolaños

http://www.kritike.org/journal/issue_19/mancenido-bolanos_december2016.pdf ISSN 1908-7330 
For him, democracy entails developing knowledge among the people until they are able to utilize it as a guide to a collective action. ${ }^{4}$

Loomis and Rodriguez ${ }^{5}$ pointed out that democracy is the final object of all curricula, from which we can understand the importance of experience in education. Dewey also discusses the idea of co-operative problem-solving. Another thing that we must take from Dewey is his belief that each student must be addressed differently. We must understand that we are not to plan a generalized method of instruction because each class consists of diverse students.

\section{Dewey's Critique of the Traditional Pedagogy}

Dewey's Democracy and Education shows how education can be used as a tool to transform not just the self but also the society. Here, Dewey outlines the importance of education in how we deal with the world in general. He suggests that each discipline must realize that there should be no separation between theory and experience and that the discipline must be reconstructed as an "enterprise aimed at personal and collective well-being." 6 Dewey criticizes the traditional method of teaching as he suggests better ways of educating students, that is, by teaching them how to think and making both the teachers and students realize that learning is not a mere repetition of what are written in the textbooks. Traditional method of teaching can be understood as a method of handling down knowledge from the teacher to the students. The teacher discusses the topics leaving little room for students to think and verbalize their thoughts. Education, he says, "is a fostering, a nurturing, and a cultivating process." 7 Therefore, we have to be cautious in dealing with the young, as it can be inferred that our failure to mold them well destroys not only the child but also the society. With the ills of the educational system and the society, and with rulers whose interests benefit only their own intentions, he asks, "Who, then, shall conduct education so that humanity may improve?"8

Dewey has a strong take on the reform of education. In his essay, "Education as Engineering," he notes that we have thought of education long enough, but not long enough to build steel bridges. He likens education to engineering in that it serves as a process of forming the individual. He

\footnotetext{
${ }^{4}$ Ibid.

5 Steven Loomis and Jacob Rodriguez, "The Individual-Collective Problem in Education: The Special Cases of John Dewey and Human Capital Theory," in Oxford Review of Education, 35:4 (2009), 509-521.

${ }^{6}$ Maughn Gregory and David Granger, "John Dewey on Philosophy and Childhood," in EEC/ Education and Culture, 28:2 (2012): 1-26.

${ }^{7}$ John Dewey, Democracy and Education (USA: Feather Trail Press, 2009), 9.

${ }^{8}$ Ibid., 53.
}

(c) 2016 Marella Ada V. Mancenido-Bolaños http://www.kritike.org/journal/issue 19/mancenido-bolanos december2016.pdf ISSN 1908-7330 
criticizes the system, saying that it "represents not thinking but the domination of thought by the inertia of immemorial customs." ${ }^{9}$ He adds that although there are certainly new methods being introduced into the system, only a few receptive minds are benefitting from them. Those belonging to the old system and habits are critical of the new methods, which often end up unrecognized if not unfunctional. He strongly points out, "There is at present no art of educational engineering. There will not be any such art until considerable progress has been made in creating new modes of education in the home and school." 10 One of the reasons why such is the case is because teachers lack the imagination and courage to design and adopt new methods. Dewey emphasizes that there is a need for educators to be scientific in their teaching. He insists, "Teachers who are to develop a new type of education need more exacting and comprehensive training in science, philosophy and history than teachers who follow conventionally safe lines." 11

Dewey emphasized that "unless our schools take science in its full relation to the understanding of forces which are now shaping society and still more, how the resources of the organized intelligence that is science might be used in organized school action, and the outlook for democracy is insecure." 12 During his time, he has already discussed how the narrow mindedness of teachers has destroyed the progress of education. Unless teachers become pioneers of learning, imaginative enough to place together what is known and what is to be experienced, we cannot say that our institutions of learning have advanced. He notes that what really exists in schools are "habits and customs rather than ... any deliberate autocracy." 13 Dewey has time and again emphasized the important role of educators in honing of the minds of the society; they play a delicate role in "developing the character and good judgment in the young." 14

\section{The Role of Education in the Development of Students}

According to Dewey, "the business of education is rather to liberate the young from reviving and retraversing the past that could lead them to a recapitulation of it." ${ }^{15}$ He does not disregard the past; however, he wishes to show that our education should not be limited by it and by our biological heredity. Heredity for him limits education. It anchors the student to

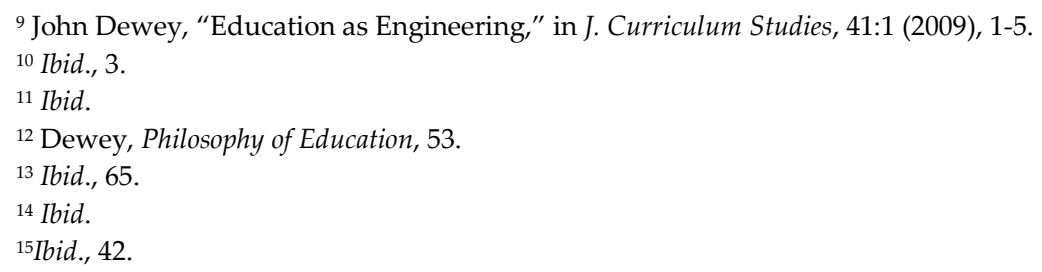

(C) 2016 Marella Ada V. Mancenido-Bolaños http://www.kritike.org/journal/issue 19/mancenido-bolanos december2016.pdf ISSN 1908-7330 
something that is long gone and hinders the student from facing what is already present. Dewey suggests that we must keep the learning process alive as it is only through this that we can keep it alive in the future. The past is only significant if it intertwines with the present and the future and not the other way around. We must concern ourselves with present circumstances to be able to address the present predicaments, instead of just clinging on to the past which may no longer be significant. In education, in particular, we must be able to adapt to the present needs of the students. If educators claim that students have changed over the years, then the system must move to address the change in the attitude of the students. Another way of looking at it is that, we may be presenting the habits of the past to the children, thereby hindering them from discovering things by themselves. Teachers may be imposing many habits and values on the children that children are no longer able to build on their own.

Dewey suggests several purposes of education. First, to have a foresight of the results which stimulate the person to think and look ahead. We cannot speak of an aim unless there is an ordered process to achieve it. Dewey notes that the goal in education must be based on the present experience and conditions of the students; from there we can draw activities and theories to be used. Readymade theories and activities that seek anticipated results are not helpful because they limit learning possibilities. We must note that every aim is experimental and that there is a need to modify it whenever the situation calls for a revision. Dewey emphasizes that if it gets in the way of human common sense, then the situation does harm. "It is well to remind ourselves that education as such has no aims; only persons, parents and teachers, etc., have aims, not an abstract idea like education." 16 Dewey is critical of the manner in which aims in education are formulated by authorities and then made to fit into the system. Children may not necessarily be capable of accomplishing such aims for the very reason that their experiences and background do not match the very generic and universal aim that is being posited by the system. Dewey notes, "In education, the currency of these externally imposed aims is responsible for the emphasis put upon the notion of preparation for a remote future and for rendering the work of both teacher and pupil mechanical and slavish."17 Gregory and Granger argue that "modern education has aimed to move children immediately away from their perceived irrationality." 18

The second purpose that Dewey suggests is social efficiency, indicating "the importance of industrial competency."19 Education should

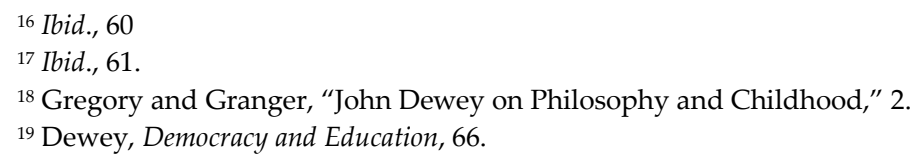


translate to employment. A man who is not able to contribute economically to the society is a drag or parasite to others. ${ }^{20}$ One should be able to make way "economically in the world and manage economic resources usefully" instead of reducing education to a mere display or luxury. ${ }^{21}$ Nevertheless, Dewey warns us of the danger of learning very specific skills because when the ways of occupation change, the individual might be left behind by progress. He also predicted that industries might eventually dictate the content of curricula. - Today institutions of higher learning have reconfigured their curricula in order to meet the demands of the industries. Industries, in some cases, have dictated to the institutions which courses to offer and which courses to close down. In a lecture given by Jonathan Kozol during the 2015 Plato conference at the University of Washington, he noted that the curriculum has been demanded by business and economics, schools actually answer to the demands of the business industry. ${ }^{22}$

Dewey notes the importance of fostering good habits of thinking. He is critical of the practice of spoon-feeding children. He emphasizes that children must learn how to think independently. The problem with the current system is that students are more concerned about meeting a particular standard or grade. They are troubled by how they are to please their teachers through their exams and deportment. As opposed to standard and grade oriented learning, Dewey proposes that students should take advantage of their various practical experiences because they are more capable of helping them during difficult life situations. Knowledge, according to Dewey, is the "working capital, the indispensable resources of further inquiry, of finding out, or learning more things." ${ }^{23}$ Dewey, however, suggests that ordinary experiences should be mediated by the school in order to them to be translated into knowledge. ${ }^{24}$ As such, he urges institutions to create an environment that is more conducive to practical learning. The creation of laboratories, shops and gardens are a means to enrich the experience and understanding of students. It must be understood that "thinking is a method of educative experience." We must provide our students with a genuine situation of experience, genuine problems developed within this situation, information to make needed observations, suggested solutions and, lastly, opportunity and occasion to test these ideas. ${ }^{25}$

\footnotetext{
${ }^{20}$ Ibid.

${ }^{21}$ Ibid.

${ }^{22}$ Jonathan Kozol, “The Big Questions are Already in the Hearts of Children, The Role of Philosophy in the Classroom of our Public Schools in an Age when Standardized Instruction is Crowding out the Domain of Inquiry," paper presented during the PLATO Conference, University of Washington, Seattle, 29 June 2015.

${ }^{23}$ Dewey, Democracy and Education, 87.

${ }^{24}$ Ibid., 88.

${ }^{25}$ Ibid., 87.

(c) 2016 Marella Ada V. Mancenido-Bolaños http://www.kritike.org/journal/issue 19/mancenido-bolanos december2016.pdf ISSN 1908-7330

(cc) BY-NC-ND
} 
Dewey notes that the individual thrives in a society; the growth of the individual and the sustenance of the society are highly dependent on the transmission of habits, thinking and feeling through communication. ${ }^{26}$ "Men live in a community in virtue of the things which they have in common. What they must have in common is the way in which they come to possess things in common. ${ }^{27}$ To live in a community means that one must be able to communicate with the rest of its members and be secured that what has been communicated is understood. As pointed out above, for Dewey, experience plays an integral part in education. "The experience has to be formulated in order to be communicated. To formulate means to go out of it, seeing it as another so that it may be go into such form that he can appreciate its meaning." 28 There is a need to communicate our experiences, this way we are able to evaluate them. Dewey holds that all communication is educative; one enlarges one's experiences through communicating with the other. Students must be able to share their experiences until they become a common possession of the community. ${ }^{29}$

Dewey also looked into the significance of habits in educating the young. He considers habits as expressions of growth and the ability to use natural conditions as means to an end. ${ }^{30}$ The habits of language are nurtured through exposure to vocabulary and the mother tongue. Speech habits may be corrected. "Yet in times of excitement, intentionally acquired modes of speech often fall away." ${ }^{31}$ Language plays an important tool in relating with the community; however, Dewey cautions us of the common notion that knowledge may be directly passed on through language. ${ }^{32}$ We must understand that the mere transmission of facts from one person to another is not enough; these persons should at least have a shared experience to be understood. Dewey makes use of the work "hat" as an example. The child who is learning how to read will not comprehend what the word means unless "the child and the adult use the object hat in a common experience." 33

Another form of habit relates to one's manners, which Dewey claims to have come from good breeding. Manners are perfected through constant conscious correction and instruction. He considers manners as minor morals. Lastly, he considers good taste and aesthetic appreciation as a habit that must be formed among the young. "If the eye is constantly greeted by harmonious objects, having elegance of form and color, a standard of taste naturally grows

\footnotetext{
${ }^{26}$ Ibid., 5.

${ }^{27}$ Ibid.

${ }^{28}$ Ibid., 6.

${ }^{29}$ Ibid., 8.

${ }^{30} \mathrm{Ibid} ., 27$.

${ }^{31}$ Ibid., 13.

${ }^{32}$ Ibid., 11.

${ }^{33} \mathrm{Ibid}$.
}

(c) 2016 Marella Ada V. Mancenido-Bolaños http://www.kritike.org/journal/issue 19/mancenido-bolanos december2016.pdf ISSN 1908-7330 
up. The effect of a tawdry, unarranged, and over-decorated environment works for the deterioration of taste." ${ }^{34}$ All these three habits must come together, they must be reflected upon to say that the student has arrived at a conscious thinking and apt conclusion. Dewey notes that "there may be training, but no education. Repeated responses to recurrent stimuli may fix a habit of acting in a certain way." 35 The student should be able to understand the reason behind every action, more so the reason behind the responses to each stimulus, to be able to claim that he has learned and that he is not merely imitating their models. "Idiots are especially apt at this kind of imitation; it affects outward acts but not the meaning of their performance." In another circumstance, he noted that, "savage is merely habituated, whereas a civilized man has habits to transform his environment." 36

\section{The Role of Democracy in Education}

A more society-centered aim is civic efficiency or good citizenship. This aims to make students more mindful of their society. "It makes an individual a more agreeable companion to citizenship in the political sense." 37 It involves teaching students how to relate to others. It encourages persons to make intelligent choices which will be beneficial not just to the self but also to the society.

Dewey emphasized that aims should not be externally imposed or ready-made. They must spring from the needs of the students. ${ }^{38}$ Dewey's work is concentrated on producing a high-quality teacher exchange with the individual children, productive students who will later on engage themselves with the collective and will have the ingenuity to provide technical skills to enable students to be a part of the collective. ${ }^{39}$

However, Peters criticized Dewey for being idealistic. He notes that Dewey's Democracy and Education has failed to create a balance between personal preoccupations and public policies. ${ }^{40}$ It may be true that the dualism between the private and the public spheres appears in Dewey's work; however, I believe that the balance between these two spheres can only be created once the individual is able to master the self and is ready to commune with the public. It is for this reason that Dewey stresses the idea of personal experience and space; it is only by recognizing the experiences and spaces of

\footnotetext{
${ }^{34}$ Ibid., 13.

${ }^{35}$ Ibid., 19.

${ }^{36}$ Ibid., 28.

${ }^{37} \mathrm{Ibid}$.

38 Peters, John Dewey Reconfigured, 68.

${ }^{39}$ Loomis, and Rodriguez, "The Individual-Collective Problem in Education," 514.

${ }^{40}$ Peters, John Dewey Reconfigured, 77.
}

(C) 2016 Marella Ada V. Mancenido-Bolaños

http://www.kritike.org/journal/issue 19/mancenido-bolanos december2016.pdf

ISSN 1908-7330

$(c))$ BY-NC-ND 
each member of the community that we can provide a balanced relationship between the two spheres.

Dewey also proposes that we should include culture as a part of our aim. This involves the cultivation of respect and appreciation for ideas, the arts and the broad human interests. ${ }^{41}$ Appreciation of the art and the humanities could help people become more humane. The danger is when culture is associated with social division, when the experience of culture is equated with an inner personality, refinement, or polish. These are signs of social divisions that result in cloistered packs.

Dewey is aware of the fact that the society is composed of varied social groups; it is for this reason that he suggests a variety of quality approaches to education to meet the demands of a life that prevails in a particular group. We cannot visualize an ideal society or an ideal educational system - both should be addressed as they exist for us to be assured that "our ideal is a practicable one." $42 \mathrm{He}$ underscores the essential role of the family in society, stating that we find in each family "material, intellectual and aesthetic interest in which all participate." 43 The progress of every member affects the others. In time, each family member relates to the society where they eventually commune; it is for this reason that our society is varied. This diversity, however, is necessary in the education of the youth. The separation of the privileged and unprivileged in the school system results in the lack of intellectual balance in the system. The privileged ones become unaware of the experiences of the unprivileged and vice versa, but each experience is just as real as the other. This is why Dewey proposes democracy in education. Democracy for him must not be understood only in the political sense. "It is primarily a mode of associated living, of conjoint communicated experience," 44 where individuals recognize the action of the community. One takes into account the actions of the others to affect one's own-this shall break the "barriers of class, race and national territory which kept men from perceiving the import of their society." 45 Dewey acknowledges social stratification in the society and warns us that there should be enough and equal intellectual opportunities for all; otherwise, the development of the society will be solely dependent on the members of the ruling class who have access to education. Loomis and Rodriguez support this claim, affirming that education has affected human capital. This "competition in the labor market does not commence with employment," they say, "It begins in school." 46 The

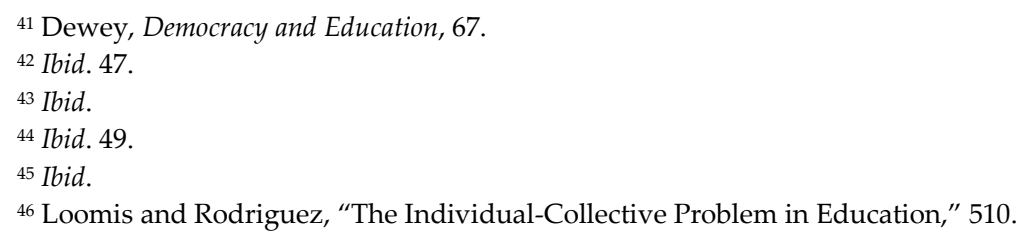




\section{THE PROBLEM OF EDUCATION IN THE PHILIPPINES}

higher the educational attainment of the individual, the higher his chances are of getting a better employment. This situation now degrades disadvantaged individuals as their chances of making their lives better become tighter. Loomis and Rodriguez are concerned with students having lower income backgrounds - these students have a lesser chance of being a part of the learning institution. They have less opportunity to pursue higher studies, and so they acquire fewer skills and less knowledge; hence, they have a smaller chance at meeting a certain standard set by the labor industry. ${ }^{47}$

In the previous discussions, it was shown that Dewey is somehow critical of the division of classes which also manifests itself in education, particularly in the way members of the different classes are educated. He is very much aware of the fact that education is necessary for the conduct of life. It prepares students to be a part of the society; particularly, it prepares students to be a part of the work force-the work force being a tool for them to sustain their lives economically. Dewey made a distinction between labor and leisure stating that education prepares students for useful labor and education for leisure. Labor is qualified by work that is perfected or learned though habit; while leisure is qualified by work that utilizes the intellect. 48 Dewey is arguing that the educational system itself has created the division between classes. The masses are educated for utility while the upper class is educated for the culture of leisure. What the system fails to do is to extend higher forms of education to a wider public, regardless of class, so that opportunities are democratized. For Dewey, the democratization of education results in the wider appropriation of critical thinking.

The democratization of education, therefore, result in the training of a critical mass that will the what is good for the society over personal good. We might have citizens who put others into consideration before themselves. For Dewey, a good society is an "efficient" society and efficiency must characterize the experience of the members of society. Dewey highlights that education must be a reconstruction of experiences. "Infancy, youth, adult life, all stands on the same educative level in the sense that what is really learned at any and every stage of experience constitutes the value of that experience." 49 Each experience can contribute to the understanding of future experiences. Someone doing a laboratory experiment, for example, commits mistakes along the way, but he eventually perfects his craft.

Dewey hopes that through the educational system we can somehow change society. According to him, reconstruction of experience may be social as well as personal. He uses progressive communities as an example where the experiences of children are shaped so that instead of "reproducing current

\footnotetext{
47 Ibid., 517.

${ }^{48}$ Dewey, Democracy and Education, 136.

${ }^{49}$ Ibid., 77-83.
}

(C) 2016 Marella Ada V. Mancenido-Bolaños http://www.kritike.org/journal/issue 19/mancenido-bolanos december2016.pdf ISSN 1908-7330

$(\mathrm{cc}) \overline{\text { BY-NC-ND }}$ 
habits, better habits shall be formed." 50 In this way, when the youth become adults they will become an improvement of the previous generation and may consciously act to eliminate the ills of the society.

How then do we address the problem of education using Dewey's thoughts on education? The above discussion points to the view that, for Dewey, the ultimate purpose of education is the democratization of the worldview of the members of a community, that is to say, the development of a sense of valuing others. ${ }^{51}$ The dualism between self-sacrifice and selfperfection must be addressed. Hence, it is the task of the educational system to inculcate among the students that social efficiency and culture must work together. It is the task of the institution of learning to teach that society is as important as the self. Institutions of learning must usher the development of the nature of each student without hampering their growth. They must teach the value of man's relatedness with the society as a whole. Students in turn must realize the essence and value of being able to contribute to the development of the society and not be a burden to the state. Students' appreciation of their own culture and arts will keep them close to their origin. The achievement of all these signals that we have fulfilled the primary aims of education which is to develop a citizenry who are willing enough to help in the development of their society.

\section{Education in the Philippine Context}

Despite the evolution of basic and secondary education in the Philippines, there has not been a clear philosophical grounding for the changes in the curriculum. Several texts show a number of reasons why the curriculum has failed to address the needs of the students. Some claim that it is because of the inadequacy of training for teachers; others would claim that it is caused by economic and political priorities of the government officials. The most convincing account, for me, is Leonardo Estioko's observation that the deficiencies in the country's educational system is profoundly tied to the pathological nature of Philippine bureaucracy. ${ }^{52}$ Estioko, moreover, notes that the lack of enthusiasm among educators to change the system is due to this pathological bureaucracy. Furthermore, the Philippine curriculum suffers from its undecidability to focus on either technical skills or higher education. "There is hardly any socio-political awareness in the minds of graduates. The first thing they have in mind is to seek employment." ${ }^{53}$ The

\footnotetext{
${ }^{50} \mathrm{Ibid} ., 45$.

${ }^{51}$ Ibid., 67.

52 Leonardo R. Estioko, History of Education: A Filipino Perspective (Philippines: Logos Publication, Inc.,1994), 205.

${ }^{53} \mathrm{Ibid} ., 207$.
}

(c) 2016 Marella Ada V. Mancenido-Bolaños http://www.kritike.org/journal/issue 19/mancenido-bolanos december2016.pdf ISSN 1908-7330 


\section{THE PROBLEM OF EDUCATION IN THE PHILIPPINES}

solution that he proposes is the determination of an appropriate philosophy of education, "only after then can an educational system devise a responsive curriculum." 54 He notes that a "Filipino philosophy of education must be borne out of the common reflection and effort of the majority." 55

Adelaida Bago, in her book Curriculum Development, The Philippine Experience, ${ }^{56}$ notes that there is a need to identify a philosophy of education before the formulation of a curriculum, but one can notice, that she presented a general theory with an encompassing definition for each theory. She enumerated philosophies such as perennialism, essentialism, progressivism and reconstructionism without thoroughly discussing each and without qualifying how these philosophies could help in shaping the educational system. Bago is proposing a convoluted philosophy that may eventually backfire. We cannot locate, in Bago's proposal, any of the goals that lead to the transformation of the individual student to being more critical or more rational. This is because the present system understands education as a "mere handling down of traditions, beliefs, values, customs behavioral patterns through oral means and immersion." 57

Isagani Cruz in his book The Basic Education Curriculum in 17 Easy Lessons, discussed the objective of the elementary education curriculum that is "develop the spiritual, moral, mental and physical capabilities of the child, provide him/her with experiences in the democratic way of life, and inculcate ideas and attitudes necessary for enlightened, patriotic, upright, and useful citizenship." 58 This supports my earlier claim that the curriculum does not prepare our students to think critically, it prepares our students to be productive members of the society.

One of the reasons why reforms in the Philippine educational system does not reform at all is because each president eyes on a different program focus, and when one's term ends, the department's program objective changes as well. It could be understood that there is no continuity in the program. During the time of Ferdinand E. Marcos Sr., the department's education agenda was in support of the New Society Vision. He wanted the Filipinization of curricula from primary to tertiary level. During the 1970s1980s, the Department of Education's goal was one with Marcos' views- that

\footnotetext{
${ }^{54}$ Ibid.

${ }^{5}$ Ibid., 96.

56 Adelaida Bago, Curriculum Development, The Philippine Experience (Manila: De La Salle University Press, 2001), 110.

${ }^{57}$ Ibid., 114.

58 Isagani Cruz, The Basic Education Curriculum in 17 Easy Lessons (Manila: Anvil Publishing, Inc., 2003), 93.
}

(C) 2016 Marella Ada V. Mancenido-Bolaños http://www.kritike.org/journal/issue 19/mancenido-bolanos december2016.pdf ISSN 1908-7330 
is "to utilize education as an instrument to achieve national development." 59 The president wanted to boost agriculture and countryside development, so the "policies and training for the tertiary is focused on agriculture as well as technical and vocational courses." 60 The government wanted to use education as a tool for social transformation- but this transformation did not speak of educating students to become better thinkers, they trained the students to look at education as a tool for future employment that would translate to better man-power and better economy.

During the time of Corazon C. Aquino, the free secondary education was instituted, the Republic Act 6728 on the Government Assistance to students and teachers in private education and the promotion of continuing education was passed. ${ }^{61}$ She allotted funds to help finance the education of under-privileged students and continuing education of teachers.

The Aquino administration also introduced values education in the new elementary and secondary curriculum. The reason for its inclusion is for the improvement of human resource with a balanced intellectual, physical, moral and spiritual well-being.

The term of Fidel V. Ramos was a period of computerization- he wanted school systems to be technologically at par with that of other countries. He believed that education is the key to improving the society- but by this he meant strengthening the country's economy through education. He institutionalized the trifocalization of the education agency, namely: Department of Education Culture and Sports, Commission of Higher Education, Technical Education and Skills Development Authority. When he ordered for the enhancement of the curriculum, the department moved to improve the quality of teaching science and mathematics. When he said he wanted to improve the quality of teachers, the department established Teacher Education Council which "worked at raising the dignity of teachers as professionals and improving the prospects of continuous professional development in a rapidly changing environment." 62

Joseph Estrada was not able to put forward much changes to the educational system, given the fact that his term lasted only for two years and six months. However, it was during his term that the department adapted UNESCO's four pillars of education: Learning to know, learning to do, learning to live together and learning to be. ${ }^{63}$

\footnotetext{
${ }^{59}$ Mona Valisno Dumlao, The Nation's Journey to Greatness: Looking Beyond Five Decades of Philippine Education, (Makati City, Philippines: Fund for Assistance to Private Education, 2010), 18

${ }^{60} \mathrm{Ibid}$.

${ }^{61}$ Ibid., 35.

62 Ibid., 55.

${ }^{63}$ Ibid., 58.
}

(c) 2016 Marella Ada V. Mancenido-Bolaños http://www.kritike.org/journal/issue 19/mancenido-bolanos december2016.pdf ISSN 1908-7330 


\section{THE PROBLEM OF EDUCATION IN THE PHILIPPINES}

Gloria Macapagal-Arroyo continued the reform agenda of the previous administration. To add to that, she started the 4Ps program which intends to support the health and education needs of children from extremely poor households. She also established Presidential Task Force for Education which then produced the Philippine Main Education Highway which aims to come up with a seamless education for students, to increase the competitiveness of Philippine Education and the industries by reasserting the aspirations of universal school participation. ${ }^{64}$ It improved linkages between "postsecondary education and training, technical and academic needs of the industries." 65 From here, we understand that the Philippine Educational System was once again used as an investment capital to help boost the economy of the country by supplying graduates whose skills are matched with the dictates and demands of the industry.

Benigno Aquino Jr.'s term ushered in a complete turn in the educational system as it introduced the 12-yr basic education cycle which mandated that children at the age of 5 should already start with formal schooling that is kindergarten, this is then followed by a six-year primary education, four-year junior high school and two-year senior high school. This cycle aims to "provide sufficient time for mastery of concepts and skills, develop lifelong learners, prepare graduates for tertiary education, middlelevel skills development, employment, and entrepreneurship." 66

His ten-point agenda appears to be a continuation of the previous administration's educational goals, what makes revolutionary is the 12-year basic education cycle that is spiral progression from kindergarten to senior high school; with the inclusion of the academic track (1. Accountancy, Business and Management Strand, 2. Humanities and Social Sciences Strand, 3. Science, Technology, Engineering and Mathematics Strand); TechnicalVocational Livelihood track, Sports track, Arts and Design Track. Its outcome is yet to be realized as its implementation has just started during the school year 2012-2013. “Grade 1 entrants of S.Y. 2012-2013 are the first batch to fully undergo the program, and current $1^{\text {st }}$ year Junior High School students (or Grade 7) are the first to undergo the enhanced secondary education program." 67 It would be necessary to note though, that the Aquino administration was able to address the ten-point agenda as evidenced in UNESCO's report. ${ }^{68}$ According to Ecclesiastes Papong, John Dewey have

\footnotetext{
${ }^{64}$ Ibid., 72.

${ }^{65}$ Ibid.

66 See "The K to 12 Basic Education Program," in the Official Gazette, <http://www.gov.ph/k-12/>, 14 November 2016.

${ }^{67}$ Ibid.

68 See “Education for All 2015 National Review Report: Philippines," a report submitted by the relevant national authorities to UNESCO at the World Education Forum, Incheon, Republic of Korea, 19-22 May 2015.
}

(C) 2016 Marella Ada V. Mancenido-Bolaños http://www.kritike.org/journal/issue 19/mancenido-bolanos december2016.pdf ISSN 1908-7330

$(c))$ BY-NC-ND 
influenced the curriculum of the 12-year basic education cycle, in such a way that it is now learner-centered and it utilizes inquiry-based approach, however, there might be a need to check on schools whether teachers are really utilizing these methods in their respective classes. ${ }^{69}$

Emerita Quito notes that we must first locate the Filipino identity before we can come up with a valid Philosophy of Education that could be applicable for Filipinos. She notes that there is a need to understand our history. The educational system must teach its students not to despise their own, she proposes decolonization of the system. ${ }^{70}$

\section{Conclusion}

As argued by Estioko and Quito, the Philippine Educational system is not anchored on any concrete philosophy, this fact already strips the system of any direction. Dewey has already emphasized the role of teachers in revolutionizing the educational system- he holds that progress will remain elusive until teachers become more open to genuine change in the system; or until teachers are well-trained in science, philosophy and history.

As mentioned by Dewey, an education system must have an aim- to have a foresight of results which stimulate the person to think and look ahead, to realize the importance of industrial competence and to produce good citizens. The creation of a universal pedagogy may be the least helpful in achieving these aims, because according to Dewey, the pedagogy used should answer to the uniqueness of the traditions and culture of a particular community. As discussed by Bautista, Bernardo and Ocampo, in 1925, one of the reasons why students are not able to meet the standard of learning is because they were using a curriculum that was borrowed from the Americans, aside from the fact that there was an insistence in the use of English as the medium of instruction, students were probably not able to relate to the curriculum that was culturally different from theirs. ${ }^{71}$

There have been several criticisms of the Philippine educational system, and all these criticisms talk about almost the same things: drop-out rate, students' inability to meet standards of learning, untrained teachers,

${ }^{69}$ Ayala Foundation's Centex Manila and Centex Batangas are two schools in the country which utilizes inquiry-based approach in the classroom as influenced by Matthew Lipman's community of inquiry. Lipman's community of inquiry was heavily influenced by Dewey's take on inquiry-based approach in learning.

70 Emerita Quito, "A Philosophy for Philippine Education," in Visions for Education: Essays on Philippine Education in Honor of Br. Andrew Gonzales, FSC, ed. by Allan B.I. Bernardo and Robert T. Borromeo (Manila: DLSU Press, Inc., 2005), 67-73.

${ }^{71}$ Ma. Cynthia Rose B. Bautista, Allan B.I. Bernardo, and Dina Ocampo, "When Reforms Don't Transform: Reflections on Institutional Reforms in the Department of Education," in Human Development Network Discussion Papers Series, 2 (2008/2009), 2.

(C) 2016 Marella Ada V. Mancenido-Bolaños http://www.kritike.org/journal/issue 19/mancenido-bolanos december2016.pdf ISSN 1908-7330 


\section{THE PROBLEM OF EDUCATION IN THE PHILIPPINES}

unreliable textbooks to name a few. The problem lies in the fact that there has been no continuity in the government's education agenda from 1965-1998 and its bureaucratic practices as discussed earlier. The thrust of education in the Philippines is dependent on the goals set by the president for the state. These must have addressed Dewey's aim- that is to realize the importance of industrial competence, however, if we are only to teach our students to supply man-power to the state, then we have failed to teach them how to think. As Dewey argued, there is education for leisure which makes use of one's intellect and education for labor which utilizes habit formed through repetition. If the state continues to teach students the importance of their economic contribution to the society- then, they are only teaching them an aspect of how it is like to be a good citizen of the state.

We can continuously enumerate the problems of the educational system-lack of funding, lack of facilities and so on without pinning down a concrete solution to solve the problem of the quality of education and quality of citizens it is producing. It might then be timely for institutions responsible for drafting the curriculum and institutions of learning responsible for the training of future teachers to once again consider re-learning Dewey's thoughts on education and how it could work alongside philosophy, as Dewey mentioned "If we are willing to conceive education as the process of forming fundamental dispositions, intellectual and emotional, toward nature and fellow men, philosophy may even be defined as the general theory of education." 72 Unless we have a concrete philosophy of education ${ }^{73}$ as a basis for all the education agenda, the same problems on the quality of education would continue to exist.

Department of Philosophy, University of Santo Tomas, Philippines

\section{References}

Bago, Adelaida, Curriculum Development: The Philippine Experience (Manila: De La Salle University Press, 2001).

Bautista, Ma., Cynthia Rose B., Allan B.I. Bernardo, and Dina Ocampo, "When Reforms Don't Transform: Reflections on Institutional Reforms in the Department of Education," in Human Development Network Discussion Papers Series, 2 (2008/2009).

Cruz, Isagani, The Basic Education Curriculum in 17 Easy Lessons (Manila: Anvil Publishing, Inc., 2003).

Dewey, John, Democracy and Education (USA: Feather Trail Press, 2009).

\footnotetext{
72 Dewey, Democracy and Education, 177.

${ }^{73}$ By this I mean, having a concrete Philosophy of Education that could have been taken from the works of Philosophers and theorists.

(C) 2016 Marella Ada V. Mancenido-Bolaños

http://www.kritike.org/journal/issue 19/mancenido-bolanos december2016.pdf ISSN 1908-7330

$(c))$ BY-NC-ND
} 
"Education as Engineering," in J. Curriculum Studies, 41:1 (2009). Philosophy of Education (New Jersey: Littlefield, Adams and Co., 1975).

Dumlao, Mona Valisno, The Nation's Journey to Greatness: Looking Beyond Five Decades of Philippine Education (Makati City, Philippines: Fund for Assistance to Private Education, 2010).

"Education for All 2015 National Review Report: Philippines," a report submitted by the relevant national authorities to UNESCO at the World Education Forum, Incheon, Republic of Korea, 19-22 May 2015.

Estioko, Leonardo, R., History of Education: A Filipino Perspective (Philippines: Logos Publication, Inc., 1994).

Gregory, Maughn and David Granger, "John Dewey on Philosophy and Childhood," in EEC/ Education and Culture, 28:2 (2012).

Hornedo, Florentino, "Philosophy: School of Freedom," Keynote Lecture presented at the Philosophical Association of the Philippines (PAP, Inc.) Midyear Conference 2014 (The Role of Philosophy in the K-12: Pedagogy and Content), Philippine Normal University, Manila, 24-25 October 2014.

Kozol, Jonathan, "The Big Questions are Already in the Hearts of Children, The Role of Philosophy in the Classroom of our Public Schools in an Age when Standardized Instruction is Crowding out the Domain of Inquiry," paper presented during the PLATO Conference, University of Washington, Seattle, 29 June 2015.

Loomis, Steven and Jacob Rodriguez, "The Individual-Collective Problem in Education: The Special Cases of John Dewey and Human Capital Theory," in Oxford Review of Education, 35:4 (2009).

Peters, R.S., John Dewey Reconfigured (USA: Routledge and Kegan Paul, Ltd., 1977).

Quinton, Anthony, "Inquiry, Thought and Action: John Dewey's Theory of Knowledge," in John Dewey Reconfigured, ed. by R.S. Peters (USA: Routledge and Kegan Paul, Ltd., 1977).

Quito, Emerita, "A Philosophy for Philippine Education," in Visions for Education: Essays on Philippine Education in Honor of Br. Andrew Gonzales, FSC, ed. by Allan B.I. Bernardo and Robert T. Borromeo (Manila: DLSU Press, Inc., 2005).

"The $\mathrm{K}$ to 12 Basic Education Program," in the Official Gazette, $<$ http://www.gov.ph/k-12/>, 14 November 2016.

Villacorta, Wilfredo, "Politics and Education in the Philippine Setting," in Issues in Philippine Education, ed. by Serafin V.C. Guingona (Manila: Phi Delta Kappa, 1982).

(c) 2016 Marella Ada V. Mancenido-Bolaños http://www.kritike.org/journal/issue 19/mancenido-bolanos december2016.pdf ISSN 1908-7330 